\title{
PENINGKATAN MINAT DAN AKTIVITAS BELAJAR MATEMATIKA MENGGUNAKAN MODEL MAKE A MATCH
}

\author{
Maria Oktaviani Nagur ${ }^{1}$, Melinda Rismawati ${ }^{2}$, Sirilus Sirhi $^{3}$ \\ ${ }_{1,3}^{1,3}$ Progam Studi Pendidikan Guru Sekolah Dasar, STKIP Persada Khatulistiwa Sintang \\ ${ }^{2}$ Progam Studi Pendidikan Matematika, STKIP Persada Khatulistiwa Sintang \\ e-mail: ${ }^{1}$ oktavianinagur@gmail.com,${ }^{2}$ melris 1@ yahoo.com,${ }^{3}$ sirilussirhi@gmail.com
}

\begin{abstract}
The purpose of this research is to increase the interest and learning activities of the fourth grade mathematics using make a match. The form of research is a class action study implemented in two cycles. Data sources of fourth graders, fourth grade3 teachers, learning activities and documents. The data collection tools used are observation sheets (teacher and students), poll sheets, and student responses. The results showed that: the use of the make a match on cycle 1 was gained on average of $70 \%$ with good criteris, in cycle 2 the use of make a match obtained average $95 \%$ with very good criteria occurred increase by $25 \%$. Student learning activity in cycle 1 gained an average of 64,92 \% with the active criteria of high student, in cycle 2 gained an average of $93,50 \%$ with very high student activity criteria occurred increase by 28,58 $\%$. Pool of mathematical interest in cycle 1 obtained on average 66,43\% with interest criteria, in cycle 2 obtained average 94,10\% with very interest criteria occurred increase by 27,67\%. While the students response to learning by using make a match is very positive.
\end{abstract}

Keyword: Make a Match, Math Learning Interests and Activities

\begin{abstract}
Abstrak. Tujuan penelitian ini adalah untuk meningkatkan minat dan aktivitas belajar matematika kelas IV menggunakan model Make a Match. Bentuk penelitian adalah penelitian tindakan kelas yang dilaksanakan dalam dua siklus. Sumber data berasal dari siswa kelas IV, guru kelas IV, kegiatan pembelajaran, dan dokumen. Alat pengumpulan data yang digunakan yaitu lembar observasi (guru dan siswa), lembar angket, dan respon siswa. Hasil penelitian menunjukan bahwa : penggunaan model Make a Match pada siklus 1 diperoleh rata-rata $70 \%$ dengan kriteria baik, pada siklus 2 diperoleh rata-rata $95 \%$ dengan kriteria sangat baik terjadi peningkatan sebesar $25 \%$. Aktivitas belajar siswa pada siklus 1 diperoleh rata-rata 64,92 dengan kriteria keaktivan siswa tinggi, pada siklus 2 diperoleh rata-rata 93,50\% kriteria keaktifan siswa sangat tinggi dan terjadi peningkatan 28,58\%. Angket minat belajar matematika pada siklus 1 diperoleh rata-rata 66,43\% kriteria minat, pada siklus 2 diperoleh rata-rata 94,10\% dengan kriteria sangat minat terjadi peningkatan 27,67\%. Sedangkan respon siswa terhadap pembelajaran dengan menggunakan model make a match sangat positif.
\end{abstract}

Kata Kunci: Make a Match, Minat dan Aktivitas Belajar Matematika 


\section{PENDAHULUAN}

Pendidikan merupakan sebuah usaha dimana terdapat pengajaran dan pelatihan dikhususkan untuk siswa dalam mengasah kemampuan kognitif serta keterampilan yang dimiliki agar kelak berguna bagi orang-orang disekitarnya. Salah satunya di dalam pendidikan nasional terdapat pembelajaran matematika yang sangat berpengaruh bagi kehidupan sehari-hari siswa. Kendala yang dihadapi dalam pembelajaran matematika diantaranya adalah pemahaman siswa terhadap konsep yang dipelajari masih rendah, siswa kurang bisa mengkomunikasikan ide matematisnya dalam menyelesaikan masalah, siswa masih terbiasa menghafal rumus tanpa memahami konsep pada saat belajar matematika, siswa masih salah dalam menggunakan prosedur dalam memecahkan masalah matematika. Hal ini sesuai dengan pendapat Andri \& Rismawati (2018) serta Rismawati dan Asnayani (2019) yang menyatakan bahwa pemahaman konsep merupakan dasar dari pembelajaran matematika.

Pemahaman siswa bisa ditimbulkan dari minat dan aktivitas belajar matematika itu sendiri di dalam kelas. Dengan adanya minat siswa terdorong dalam mempelajari atau mendalami materi yang diajarkan oleh guru. Tidak hanya minat keberhasilan belajar siswa diukur juga dengan aktivitas belajar siswa, baik dalam aktivitas dalam bertanya dan menjawab pertanyaan dari guru.

Berdasarkan pengamatan yang dilakukan peneliti, terdapat kondisi yang kurang mendukung, sehingga menyebabkan minat dan aktivitas belajar siswa kurang. Berdasarkan wawancara dengan siswa, menunjukan sikap bahwa pembelajaran metematika merupakan pembelajaran yang sulit di pahami, sehingga membuat siswa kurang bersemangat saat pembelajaran matematika dimulai. Dari sisi minat pada observasi awal, peneliti menemukan hanya beberapa siswa saja yang menujukan sikap senang, hal itu dapat dilihat dari segi mimik muka siswa, beberapa siswa tidak terlihat memperhatikan penjelasan dari guru dan asyik mengobrol dengan teman satu kelompoknya, serta tidak banyak dari seluruh siswa yang aktif saat bertanya dan menjawab pertanyaan dari guru.

Aktivitas belajar siswa pada saat observasi masih ada siswa yang memilih diam dan tidak ikut berpartisipasi hanya mengikuti kata-kata siswa yang dominan dikelompok tersebut. Keberanian siswa dalam mengungkapkan pendapat pun masih sangat minim, jika ditanya sudah paham semua oleh guru maka semua menjawab sudah, ketika ditanya kembali oleh guru tentang materi tersebut masih banyak siswa yang belum memahami. Terlebih juga banyaknya siswa di dalam kelas tersebut membuat guru merasa kewalahan dalam pengajaran jika hanya menggunakan metode ceramah.

Berdasarkan kondisi yang ada di lapangan, terdapat cara meningkatkan minat dan aktivitas belajar siswa dengan menggunakan suatu model pembelajaran. Salah satu model pembelajaran yang cocok 
pada pelajaran matematika adalah model Make a Match. Model Make a Match melatih siswa untuk memiliki sikap sosial yang baik dan melatih kemampuan siswa dalam bekerja sama disamping melatih kecepatan berpikir siswa.

Tujuan penelitian ini adalah untuk meningkatkan minat dan aktivitas belajar matematika kelas IV menggunakan model Make a Match.

\section{METODE}

\section{Pendekatan Penelitian}

Pendekatan yang digunakan dalam penelitian ini adalah pendekatan kualitatif. Sugiyono (2015: 9) penelitian kualitatif adalah metode penelitian yang berlandaskan pada filsafat postpositivisme, digunakan untuk meneliti pada kondisi obyek yang alamiah, peneliti adalah sebagai instrument kunci, teknik pengumpulan data dilakukan secara gabungan, analisis yang bersifat induktif, dan hasil pendekatan kualitatif lebih menekankan makna dari pada generalisasi.

\section{Metode Dan Bentuk Penelitian}

Metode penelitian ini adalah penelitian deskriptif kualitatif. Bentuk penelitian ini yaitu Penelitian Tindakan Kelas atau PTK. Menurut Sugiyono (2009: 12) dalam praktek PTK adalah tindakan yang bermakna melalui prosedur penelitian yang mencakup 4 langkah yaitu perencanaan, tindakan, pengamatan dan refleksi.

\section{Lokasi penelitian}

Penelitian Tindakan Kelas ini dilaksanakan pada semester genap dikelas IV SD Negeri 01 Sungai Ringin pada mata pelajaran matematika. Penelitian ini dilakukan di SD Negeri 01 Sungai Ringin, yang terletak di Jl. Merdeka, No. 77, Desa Sungai Ringin, Kecamatan Sekadau Hilir, Kabupaten Sekadau. Siswa kelas IV di SD Negeri 01 Sungai Ringin berjumlah 39 siswa, laki-laki terdiri dari 21 siswa dan perempuan terdiri dari 18 siswa.

\section{Teknik Dan Alat Pengumpulan Data}

Adapun teknik yang digunakan untuk pengumpulan data dalam penelitian ini adalah obeservasi langsung (guru dan siswa), komunikasi langsung (guru dan siswa), komunikasi tidak langsung (angket), dan dokumentasi.

\section{Keabsahan Data}

Keabsahan data adalah data yang tidak berbeda antara data yang diperoleh oleh peneliti dengan data yang terjadi sesungguhnya pada objek penelitian. Menurut Sugiyono (2015: 273-274) menyatakan triangulasi dalam pengujian kredibilitas ini diartikan sebagai pengecekan data dari berbagai cara, dan berbagai waktu. 1) triangulasi sumber, 2) triangulasi teknik, 3) triangulasi waktu.

\section{Teknik Analisis Data}

Menurut Sugiyono (2015: 244) teknik analis data adalah 1) Data Collection, 2) Data Reduction, 3) Data Display, 4) Kesimpulan

\section{Teknik Analisis Observasi Guru}

Analisis data dalam penelitian ini yaitu data yang bersifat kualitatif berupa informasi berbentuk data observasi aktivitas mengajar guru. Bentuk skor dihitung persentasi tiap aspek yang diamati menggunakan rumus 
Penilaian: $\frac{\text { skor perole han checklist }}{j u m l a ~ h \text { keseluru han aspek yg diamati }} 100 \%$

Kriteria menurut Juliani (2017:57) yaitu :

Table 1. kriteria analisis observasi guru

\begin{tabular}{|l|l|}
\hline Interprestasi & Kriteria \\
\hline $90-100 \%$ & Sangat Baik \\
\hline $80-90 \%$ & Baik \\
\hline $65-79 \%$ & Cukup \\
\hline $55-64 \%$ & Kurang \\
\hline$<55 \%$ & Tidak Baik \\
\hline
\end{tabular}

\section{Teknik Analisis Observasi Siswa}

Analisis data dalam penelitian ini yaitu data yang bersifat kualitatif berupa informasi berbentuk data observasi aktivitas belajar siswa. Cara menghitung persentase keaktifan siswa berdasarkan lembar pengamatan menurut Nurhikmah (2013: 21) yaitu :

Rumus : $\frac{\text { skor perole han }}{\text { skor maksimal }} \times 100$

Dengan kriteria persentasi aktivitas siswa menurut Nurhikmah (2013: 21), yaitu :

Table 2. kriteria analisis observasi siswa

\begin{tabular}{|c|l|}
\hline Interprestasi & \multicolumn{1}{c|}{ Kriteria } \\
\hline $0-24,99 \%$ & Keaktifan siswa rendah \\
\hline $25-49,99 \%$ & Keaktifan siswa sedang \\
\hline $50-74,99 \%$ & Keaktifan siswa tinggi \\
\hline $75-100 \%$ & Keaktifan siswa sangat tinggi \\
\hline
\end{tabular}

\section{Teknik Analisis Angket}

Untuk mengetahui minat belajar siswa terhadap penggunaan metode Make a Match yang diterapkan di kelas, maka peneliti menyebarkan angket. Skor setiap responden diperoleh menggunakan persamaan menurut Nenggala (2018: 8):

Sk : $\frac{£ X_{1}}{X \max } \times 100$

Dengan rentang nilai:
Table 3. kriteria analisis minat

\begin{tabular}{|c|c|}
\hline Interval & Kategori \\
\hline $0-20 \%$ & Tidak minat \\
\hline $21-40 \%$ & Kurang minat \\
\hline $41-60 \%$ & Cukup minat \\
\hline $61-80 \%$ & Minat \\
\hline $81-100 \%$ & Sangat minat \\
\hline
\end{tabular}

\section{HASIL DAN PEMBAHASAN}

\section{Pelaksanaan Penelitian}

Penelitian Tindakan Kelas dilaksanakan dalam dua siklus yaitu siklus I dan siklus II. PTK dilaksnakan dalam 4 tahap, yaitu :

1. Perencanaan

Instrumen yang akan digunakan dalam penelitian ini adalah menyusun RPP, menyusun lembar angket, menyusun lembar observasi (siswa dan guru), menyusun pedoman wawancara (siswa dan guru). Setelah menyusun semua instrumen kemudian di validasi oleh validator I yaitu bapak Beny Setiawan, M.Pd, validator II yaitu ibu Nety Malahayati, S.Pd.SD selaku guru kelas IV SD Negeri 01 Sungai Ringin.

2. Pelaksanaan Tindakan

Pada pelaksanaan pembelajaran, peneliti bertindak sebagai guru dengan menggunakan model Make a Match yang didukung dengan media pembelajaran seperti kartu yang dibuat dari kertas origami dan RPP serta materi matematika tentang FPB dan KPK. Tindakan siklus I terdapat dua pertemuan, pada pertemuan I dilaksanakan pada tanggal 15 Januari 2020 pukul 08.00-09.10 WIB, pada pertemuan II dilaksanakan pada tanggal 16 Januari 2020 pukul 08.00-09.10 WIB. 
Pada siklus II, peneliti merancang RPP yang mengacu pada perbaikan tindakan pada siklus sebelumnya dan mengidentifikasi masalah yang terdapat pada siklus I yang belum teratasi dan menetapkan alternative pemecahan masalah. Pada siklus II terdapat dua pertemuan, pada pertemuan I dilaksanakan pada tanggal 20 Januari 2020 pukul 09.1511.35 WIB, pada pertemuan II dilaksankan tanggal 21 Januari 2020 pukul 07.15-8.45 WIB.

3. Observasi

Berdasarkan hasil observasi keterlaksanaan pembelajaran pada siklus I diperoleh hasil observasi dengan kategori baik. Namun terdapat kekurangan siswa pada pelaksanaan pembelajaran yang disebabkan banyaknya siswa di dalam kelas yang membuat peneliti sedikit kesulitan dalam melihat partisipasi aktif atau tidaknya dari setiap individu siswa dalam proses pembelajaran.

Berdasarkan hasil observasi keterlaksanaan pembelajaran pada siklus II diperoleh hasil observasi dengan memberikan peningkatan yang sangat signifikan terutama pada sikap memperhatiakan guru menjelaskan materi, siswa tampak sangat memperhatikan dengan perilaku yang tertib dan tenang tanpa harus ribut sendiri.

4. Refleksi

Ada beberapa yang perlu direfleksikan pada siklus I untuk perbaikan proses pembelajaran pada siklus II yaitu tidak terlaksana dengan baik aktivitas guru dan siswa dalam pembelajaran seperti guru belum dapat mengelola kelas dengan baik dan beberapa siswa tidak terlihat aktif dalam proses pembelajaran

Pada siklus II , berdasarkan hasil pengumpulan data terdapat hasil pelaksanaan dari observasi siswa dan guru, hasil angket dan respon siswa dan guru mengalami peningkatan. Siswa sudah terlihat aktif dalam proses pembelajaran. Dan guru dapat mengelola kelas dengan baik.

\section{Perbedaan Siklus I dan II}

Perbedaan terlihat pada siklus I, guru masih belum dapat menguasai kelas dengan baik, tetapi pada siklus II guru perlahan bisa menguasai kelas dengan baik. Pada siklus I, masih sedikit siswa yang terlihat aktif dan belum memahami materi yang di ajarkan, tetapi pada siklus II sebagian besar siswa terlihat antusias dalam proses pembelajaran dan proses pembelajaran dapat berlangsung dengan baik.

\section{Hasil Penelitian}

1. Observasi Guru

Berdasarkan observasi yang dilakukan oleh obsever siklus I pertemuan I, diperoleh hasil pengamatan oleh obsever sebesar $50 \%$ dengan kategori tidak baik. Pada siklus I pertemuan II, diperoleh hasil pengamatan oleh obsever sebesar $70 \%$ dengan kategori cukup baik. Siklus II pertemuan I, diperoleh hasil pengamatan oleh obsever sebesar $90 \%$ dengan kategori baik. Pada siklus I pertemuan II, diperoleh hasil pengamatan oleh obsever sebesar $100 \%$ dengan kategori sangat 
baik. Hasil observasi guru dapat dilihat

dalam table dan grafik sebagai berikut :

Table 4. Hasil Observasi Guru Siklus I dan II

\begin{tabular}{|l|c|c|l|l|}
\hline No & Siklus & Pertemuan & \% & Kriteria \\
\hline 1 & I & 1 & 50 & Tidak baik \\
\hline 2 & II & 2 & 70 & Cukup baik \\
\hline 3 & I & 1 & 90 & Baik \\
\hline 4 & II & 2 & 100 & Sangat baik \\
\hline & & & \\
\hline
\end{tabular}

Gambar 1. Hasil Observasi Guru

2. Angket minat siswa

Perhitungan hasil angket dapat dilihat dari hasil rekapitulasi angket minat siswa dapat dilihat dari table dan grafik sebagai berikut:

Table 5. Hasil Angket Minat Siswa Siklus I dan II

\begin{tabular}{|c|c|c|c|}
\hline $\begin{array}{c}\text { Hasil } \\
\text { Angket }\end{array}$ & $\begin{array}{c}\text { Rata- } \\
\text { Rata }\end{array}$ & Skor & Keterangan \\
\hline Siklus I & 2591 & $66,43 \%$ & Minat \\
\hline Siklus II & 3670,25 & $94,10 \%$ & Sangat minat \\
\hline \multicolumn{2}{|c|}{1079,25} & $27,67 \%$ & \\
\hline
\end{tabular}

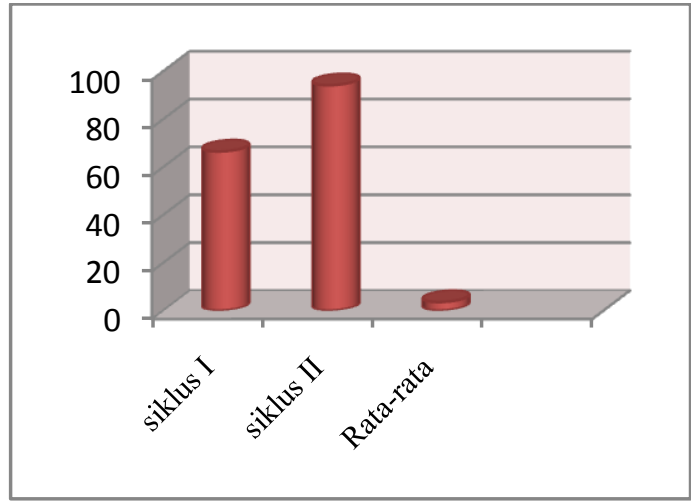

Gambar 2. Hasil Angket Minat Belajar

3. Observasi Aktivitas Belajar Siswa

Berdasarkan observasi yang dilakukan oleh observer siklus I pertemuan I diperoleh hasil dengan rata-rata $43,82 \%$ dengan kategori keaktifan siswa sedang, pada pertemuan II diperoleh hasil dengan ratarata $74,12 \%$ dengan kategori keaktifan siswa tinggi, siklus II pertemuan I diperoleh hasil dengan rata-rata $86,48 \%$ dengan kategori keaktifan siswa sangat tinggi, pada pertemuan II diperoleh hasil dengan ratarata $100 \%$ dengan kategori keaktifan siswa sangat tinggi. dapat dilihat dari table dan grafik sebagai berikut:

Table 6. hasil observasi siswa siklus I dan II

\begin{tabular}{|l|c|c|c|l|}
\hline No & Siklus & Pertemuan & $\boldsymbol{\%}$ & \multicolumn{1}{|c|}{ Kriteria } \\
\hline 1 & I & I & 43,82 & $\begin{array}{l}\text { Keaktifan siswa } \\
\text { sedang }\end{array}$ \\
\hline 2 & I & II & 74,12 & $\begin{array}{l}\text { Keaktifan siswa } \\
\text { tinggi }\end{array}$ \\
\hline 3 & II & I & 86,48 & $\begin{array}{l}\text { Keaktifan siswa } \\
\text { sangat tinggi siswa }\end{array}$ \\
\hline 4 & II & II & 100 & $\begin{array}{l}\text { Keaktifan } \\
\text { sangat tinggi }\end{array}$ \\
\hline
\end{tabular}

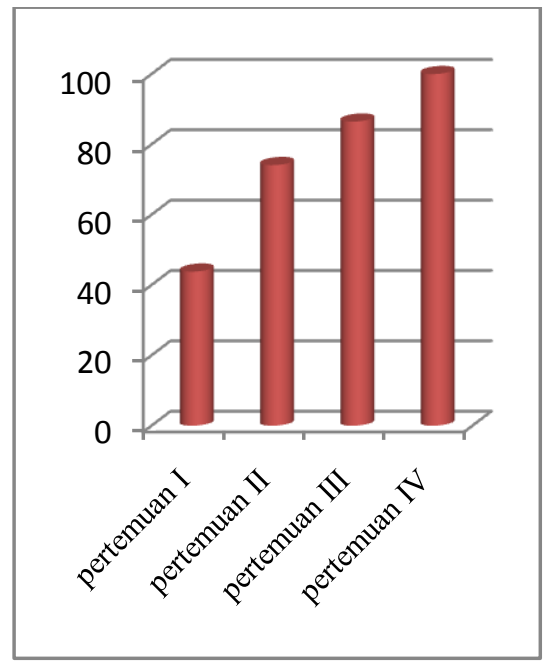

Gambar 3. Hasil Observasi Siswa

4. Hasil wawancara

a. Wawancara guru

Berdasarkan hasil wawancara guru bahwa pembelajaran yang berlangsung sangat menarik dan memuaskan siswa dan model yang digunakan sudah seusai 
dengan materi pembelajaran.

b. Wawancara siswa

Berdasarkan hasil wawancara siswa bahwa siswa merasa tertarik dan bersemangat dalam mengikuti pembelajaran matematika dengan menggunakan model Make a match. Siswa memberikan respon yang baijk pada guru.

\section{Pembahasan Penelitian}

1. Penggunaan Model Make A Match Dalam Meningkatkan Minat Dan Aktivitas Belajar Matematika Siswa

Hasil temuan penelitian pada observasi guru, peneliti menemukan fakta bahwa siswa akan lebih bersemangat pada mata pelajaran matematika, itu ditentukan pada kenyamanan antara siswa dengan guru yang mengajar. Karena jika siswa tersebut senang diajar, maka akan sangat mudah mereka memahami materi. Hal ini selaras dengan pendapat Widodo (2016: 26) menyatakan interaksi guru dan siswa yang akrab ditunjukan dengan tidak ada satupun siswa yang merasa takut ketika menanyakan kesulitan belajar siswa kepada guru, sikap guru yang humoris dan selalu memberikan motivasi kepada siswa dapat membuat siswa merasa nyaman mengikuti pembelajaran.

Menurut Tarigan (2015:56) dalam proses pembelajaran aktivitas siswa merupakan hal yang sangat perlu diperhatikan karena pada prinsipnya belajar adalah berbuat atau dikenal dengan semboyan learning by doing. Peningkatan hasil observasi guru dari siklus I ke siklus II diperoleh hasil siklus I pertemuan I dengan rata-rata $50 \%$, pada pertemuan II dengan ratarata $70 \%$ dengan kategori peningkatan $20 \%$. Pada siklus II pertemuan I dengan rata-rata $90 \%$, pertemuan II dengan rata-rata $100 \%$ mengalami peningkatan sebesar $10 \%$. Hal ini berarti nilai observasi sudah memenuhi syarat sehingga berpengaruh pada peningkatan minat dan aktivitas belajar siswa.

\section{Peningkatan Minat Belajar Matematika Siswa Kelas IV Dengan \\ Model Make a Match}

Minat pada dasarnya adalah penerimaan suatu hubungan antara diri sendiri dengan sesuatu diluar diri. Semakin kuat atau dekat hubungan tersebut, maka semakin besar minat yang ada pada siswa. Menurut Setiana ( 2016: 17) agar para siswa lebih berminat dalam belajar matematika dapat dilakukan dengan cara memperlihatkan manfaat matematika bagi kehidupan melalui contoh-contoh penerapan matematika yang relevan dengan dunia keseharian siswa, metode maupun pendekatan secara bervariasi dalam pembelajaran matematika agar tidak monoton.

Hasil angket minat belajar pada siswa menunjukan bahwa nilai rata- 
rata siklus I adalah sebesar 66,43\% dengan kategori minat, pada siklus II mengalami peningkatan yang sangat baik sebesar 94,11 dengan kategori sangat minat. Terjadi peningkatan antara siklus I dan II sebesar 27,68\%. Berdasarkan perhitungan analisis angket minat belajar siswa dapat disimpulkan bahwa siswa kelas IV SD Negeri 01 Sungai Ringin memiliki minat yang sangat tinggi dalam proses pembelajaran matematika menggunakan model Make a Match.

\section{Aktivitas Belajar Matematika Siswa} Kelas IV Dengan Menggunakan Model Make a Match

Berdasarkan observasi siswa yang telah dilakukan pada siklus I dan II, kegiatan siswa dalam mengikuti pembelajaran dengan menggunakan model Make a Match pada mata pelajaran matematika mengalami peningkatan yang sangat baik. Dalam hasil penelitian peneliti menemukan bahwa media pembelajaran dan lingkungan yang diterapkan oleh guru dan siswa sangat mempengaruhi keaktifan belajar siswa. Hal ini selaras dengan pendapat Maradona (2016) guru tidak menggunakan media pembelajaran membuat siswa jenuh dan pasif.

Pendapat lain dari Rohani (2010: 6) mengajar adalah proses membimbing pengalaman belajar. Pengalaman itu sendiri hanya mungkin diperoleh jika siswa dengan keaktifannya sendiri bereaksi dengan lingkungannya. Hasil observasi siswa pada siklus I pertemuan I di peroleh rata-rata $43,82 \%$ dengan kategori keaktifan siswa sedang, pada pertemuan II di peroleh rata-rata 74,12 $\%$ dengan kategori keaktifan siswa tinggi. Pada siklus II pertemuan I di peroleh rata-rata $86,48 \%$ dengan kategori keaktifan siswa sangat tinggi, pada pertemuan II di peroleh rata-rata $100 \%$ dengan kategori keaktifan siswa sangat tinggi.

\section{Respon Siswa Kelas IV Terhadap} Penggunaan Model Make a Match Dalam Meningkatkan Minat Dan Aktivitas Belajar Matematika

Huda (2016:254) Make a match saat ini menjadi salah satu strategi penting dalam ruang kelas, dalam pelaksanaannya siswa dilatih untuk bernalar, bekerja sama, dan membuat siswa menjadi aktif. Menurut hasil wawancara dari beberapa siswa bahwa pembelajaran Make a Match sangat menyenangkan dan sangat membantu proses belajar dan mengajar. Menurut pendapat Perdana (2018) menyatakan bahwa pembelajaran menggunakan model Make a Match memiliki banyak manfaat baik bagi guru dan siswa, manfaat tersebut diantaranya meningkatkan partisipasi siswa, menumbuhkan jiwa kompetitif siswa, serta melatih siswa untuk bicara.

Uraian di atas dapat disimpulkan 
bahwa penggunaan model Make a Match pada mata pelajaran matematika dapat meningkatkan minat dan aktivitas belajar siswa.

\section{Kelebihan dan Kekurangan Penelitian}

Kelebihan hasil penelitian yaitu proses pelaksanaan model make a match bias dilaksanakan dengan baik oleh guru dan siswa sesuai dengan RPP, siswa sangat bersemangat dan tertarik dengan menggunakan model Make a Match, siswa aktif dan antusias dalam proses pembelajaran.

Kekurangan hasil penelitian yaitu alokasi waktu yang belum secara optimal dilaksanakan karena keterlambatan beberapa siswa dalam menyelesaikan tugas pada model Make a Match, banyaknya siswa di kelas membuat peneliti sedikit kesulitan dalam memperhatikan setiap kegiatan belajar siswa di dalam kelas, dan terdapat siswa yang masih belum bisa kooperatif dalam belajar sehingga membuat peneliti sedikit kesulitan dalam mengimbangi cara belajarnya dengan siswa yang lain.

\section{SIMPULAN (PENUTUP)}

1. Penggunaan Model Make a Match dalam meningkatkan minat dan aktivitas belajar matematika siswa mengalami peningkatan dengan kategori sangat baik. Berdasarkan langkah-langkah dalam proses pembelajaran Make a Match sebagai berikut : 1) Guru menyiapkan beberapa kartu yang berisi tentang seputar materi FPB dan KPK, kartu tersebut terdiri dari kartu soal dan jawaban, 2) Setiap kelompok mendapat satu kartu dan memikirkan jawaban atau soal dari kartu yang dipegang, guru menyampaikan batas maksimum waktu yang diberikan kepada siswa, 3) Guru meminta kepada kelompok siswa yang mendapat kartu soal, jika sudah menemukan pasangan masing-masing harap segera melaporkan diri kepada guru, 4) Siswa melakukan persentasi, 5) Guru dan siswa melakukan evaluasi, 6) Menyimpulkan.

2. Peningkatan minat belajar siswa dengan model make a match pada mata pelajaran matematika terus meningkat dari setiap siklusnya dengan kategori sangat minat. Siswa lebvih aktif, senang, semangat, berani bertanya. Suasana kelas menjadi lebih interaktif dan menyenangkan sehingga tampak siswa sangat menyenangi pembelajaran matematika.

3. Peningkatan aktivitas belajar matematika siswa dengan menggunakan model Make a Match mengalami peningkatan yang sangat baik dengan kategori keaktifan siswa sangat tinggi. Siswa dapat berpartisipasi aktif dalam proses pembelajaran, siswa lebih berani dalam mengungkapkan pendapat didepan kelas dan siswa dapat bekerja sama baik pada teman sesame kelompok.

4. Respon siswa terhadap penggunaan model make a match menunjukan bahwa responden memberikan respon yang baik dan dampak yang positif. 


\section{DAFTAR PUSTAKA}

Andri \& Rismawati, M. 2018. Analisis Faktorfaktor yang mempengaruhi rendahnya hasil belajar konsep dasar matematika SD Pada Mahasiswa PGSD. Jurnal Vox Edukasi,9(2):91101

Arikunto, S. 2013. Prosedur Penelitian Suatu Pendekatan Praktik. Jakarta: PT. Rineka Cipta.

Awe \& Benge. 2017. Hubungan Antara Minat dan Motivasi Belajar Dengan Hasil Belajar IPA pada Siswa SD. Journal of Education Tecnology. Hal 231238 , (online), (http://ejournalundiksha.ac.id/index.p hp/JET/article/view/12859/0), diakses 13 Januari 2020

Herzamzam, D, A.2018. Peningkatan Minat Belajar Matematika Melalui Pendekatan Matematika Realistik Pada Siswa sekolah Dasar. Jurnal Visepena. 9: 67-80. (online). (http://visipena.stkipgetsempena.ac.id /?journal=home\&page $=$ article $\&$ op $=\mathrm{vi}$ ew\&path\%5B\%5D=193/0?). Di akses 16 mei 2019

Huda, M. 2016. Model-model Pengajaran Dan Pembelajaran. Yogyakarta: Pustaka belajar.

Murfiah, U. 2017. Pembelajaran Terpadu Teori dan Praktik Terbaik Di Sekolah
Bandung: PT. Refika Aditama.

Perdana \& Supriyono. 2017. Pengaruh Model Pembelajaran Make a Match Terhadap Hail Belajar Siswa Kelas IV SDN Semolowaru 1 Surabaya. JPGSD. Halaman 640-649. (online). (http://www.neliti.com/id/publications /255010). Diakses 13 Januari 2020

Rismawati, M \& Asnayani,M. 2019. Analisis Kesalahan Konsep Siswa Dalam Menyelesaikan Soal Ulangan Matematikan Dengan Metode NEWMAN. J.PIMAT , 1(2): 69-78.

Rusman. 2015. Model-model pembelajaran. Jakarta: raja Grafindo Persada

Sadirman. 2016. Interaksi dan Motivasi belajar dan Mengajar. Jakarta: Rajawali Pers

Slameto. 2015. Belajar dan factor-faktor yang mempengaruhinya. Jakarta: Rineka Cipta

Shoimin, A. 2014. Model pembelajaran Inovatif dalam Kurikulum 2013. Yogyakarta: Ar-Ruzz Media

Sugiyono. 2015. Metode penelitian Kuantitatif dan $R \& D$. Bandung: Alfabeta

Sukardi. 2016. Metodologi Penelitian Pendidikan Kompetensi dan Praktiknya. Jakarta: PT. Bumi Aksara 